\title{
IMPACT OF ORIENTEERING COMPETITIONS ON GROUND VEGETATION IN PINE FORESTS AT THE SEASIDE, LATVIA
}

Inga STRAUPE, Forest Faculty, Latvia University of Life Sciences and Technologies, Akademijas iela 11, Jelgava, LV-3001, Latvia, inga.straupe@1lu.lv (corresponding author)

Ieva IVBULE, Forest Faculty, Latvia University of Life Sciences and Technologies, Akademijas iela 11, Jelgava, LV-3001, Latvia, iivbule@gmail.com

\begin{abstract}
Orienteering is one of the most popular folk sports in Latvia, it involves a very large number of participants, and this number is growing every year. While participating in the competition and running through the forest, the competitors are trampling the forest floor. In Latvia, the impact of orienteering competitions has not been studied a lot, therefore when organizing competitions, disagreements arise when choosing the competition area - there are groundless suspicions that orienteering sport has a significant negative long-term impact on the forest floor. The aim of research is to assess the impact of orienteering competitions on ground vegetation in pine forests at the seaside, Latvia. The research was carried out in the orienteering competition "World Masters Orienteering Championships 2019" or "WMOC 2019" competition area, which was located in Scots pine forests in the seaside territory - in the vicinity of Bumbukalns and Garezeri. The study describes orienteering competitions and their process in forest lands; analyzes the vegetation at orienteering competition checkpoints before and after the competition; compares and evaluates vegetation changes in hilly areas on hill tops and in depressions. The study has found that orienteering competitions do not significantly affect the forest layers. It is concluded that as the distance from the control point increases, the trampling intensity decreases. The intensity of trampling does not depend only on the shape of the terrain. The effect of trampling is best seen on the moss layer.
\end{abstract}

Keywords: pine forests, forest layers, orienteering, trampling, projective coverage.

\section{INTRODUCTION}

Orienteering is one of the most popular folk sports in Latvia. It involves a very large number of participants, and this number is growing every year. From 50 to 200 participants take part in regional competitions, in national competitions the number of participants increases to 700 participants, while international competitions gather more than one and a half thousand participants. Sometimes even world-class competitions are held here, in Latvia, which welcome a few thousand participants and their supporters. Orienteering competitions take place all over Latvia, and in year 2019 competitions gathered more than 16 thousand participants who took part in competitions 121040 times (Latvian Orienteering..., 2020).

The origins of orienteering sport can be traced back to Scandinavia in the 19th century. Initially, orienteering was part of soldiers' military training to find their way in unknown territory using a map and compass. The first known public competition took place in 1897 in Norway, near Oslo (History and Facts..., 2020).

In the 20th century orienteering sport spread throughout whole Europe. Since 1962, European Orienteering Championships have been held, and since 1966, World Orienteering Championships. Afterwards orienteering sport also gained popularity in the United States and Canada (Encyclopaedia Britannica, 2020).

Orienteering sport also gained popularity in Latvia. Since 1933, orienteering competitions for beginners had been organized under the control of the Latvian Army Sports Club, and training had been organized under the guidance of specialists. In 1936, the first official orienteering competition took place (Ancient history, 2020).

Orienteering is a complex sport in which the athlete must be at the same time fast-thinking and physically strong in order to achieve the best results. In the orienteering distance, the athlete, using the orienteering map and compass, must find and check in the control points marked on the map and placed in the vicinity in the shortest time possible.

When choosing a place where to organize orienteering competitions in Latvia, one must follow the guidelines of the organization process jointly prepared by the Nature Conservation Agency (DAP) and the Latvian Orienteering Federation (LOF) (NCA and LOF..., 2014b).

The organization of orienteering competitions in one of the specially protected nature territories (SPNT) or in particular habitats is regulated by several regulations of the Republic of Latvia (DAP, LOF, 2014a):

- Law On the Conservation of Species and Habitats. Adopted on March 16, 2000;

Copyright () 2021 The Authors. Published by Vytautas Magnus University. This is an open-access article distributed under the terms of the Creative Commons Attribution License (CC BY 4.0), which permits unrestricted use, distribution, and reproduction in any medium, provided the original author and source are credited. 
- Cabinet Regulations No. 264 "General Regulations on Protection and Use of Specially Protected Nature Territories" adopted by the Cabinet of Ministers on March 16, 2010;

- Cabinet Regulations No. 940 "Regulations Regarding the Establishment and Management of Micro-reserves, Their Conservation, as well as Determination of Micro-reserves and Their Buffer Zones" adopted by the Cabinet of Ministers on 18 December 2012;

- Individual Regulations on Protection and Use of SPNTs (for instance, Gauja National Park Law, Teiči Nature Reserve Law, etc.)

Any activity is prohibited, and residence is restricted or prohibited in the strict regime zone and regulated regime zone of nature reserves and specially protected nature territories. Without the written permission of the Nature Conservation Agency, it is prohibited to organize public events in nature reserves and in nature reserves zone of specially protected nature territories in the open air, as well as camps with more than 60 people but in nature reserves zone of Gauja National Park and Kemeri National Park no more than 50 people. In micro-reserves it is prohibited to do any activity that is contrary to the objectives and tasks of the establishment of the micro-reserve, that destroys or disturbs the given specially protected species or habitat, including the organization and conduct of outdoor recreational and sports events.

The deliberate disturbance of animals of specially protected species, including birds, is prohibited. Destruction of habitats of specially protected species of plants, fungi and lichens is prohibited. Individual protection and use regulations may be developed for each specially protected nature territory They set out different requirements which must be followed while in them. In the nature park zone of Rāzna National Park, it is prohibited to organize public events in the open air with more than 100 people participating outside the designated or specially arranged places, without the written permission of the Nature Conservation Agency. In the nature reserve zone of Gauja National Park, it is prohibited to organize public events in nature from 15 March to 31 July, while from 1 August to 31 October it is allowed but no more than twice in the same territory (NCA and LOF..., 2014a).

Orienteering has an impact on nature and its values. There have been many studies around the world on the impact of orienteering competitions on protected nature territories, but mostly they are unpublished or published only in the regional language, so access to such information is limited.

International Orienteering Federation has conducted various studies and produced reports on the impact of competitions. In January 2012, the Environment Commission conducted a survey of the member countries of the federation about orienteering competitions (Laininen, 2012). Answers are given on 9 environmental factors: disturbance of mammals, wastewater treatment (showers, toilets), disturbance of birds, trampling of vegetation, disturbance of local inhabitants, traffic and its $\mathrm{CO}_{2}$ emissions, use of materials, use of energy. The results show that disturbance of mammals, wastewater and trampling of vegetation are considered to be very important factors during orienteering competitions. In relation to the ecological load, the most important factors are the trampling of vegetation and the disturbance of mammals.

Laininen (2012) emphasizes that edaphic changes in the soil, such as changes in soil moisture, erosion and structure, can also occur in connection with trampling of vegetation. As a result of compaction, the soil pores are closed, interfering with the exchange of water and gases in the soil, resulting in a lack of water and oxygen, or the exact opposite process takes place - soil leaching. Similar processes are particularly sensitive in forest habitats, while in dunes edaphic changes in the soil are even necessary because they overgrow rapidly.

The main factors influencing the resilience of nature complexes in flat areas where the slope gradient does not exceed three degrees, are the bedrock, the degree of humidity, the main tree species in the forest stand and the origin of the forest. Nature complexes with light mechanical bedrock (sand, clay sand) are less resistant to recreational loads than natural complexes with heavy mechanical bedrock (loam, clay). As a result of trampling, the first mentioned will suffer more, mainly will suffer soil and biocenoses (Чижова, 1977).

Among the Latvian researches related to the trampling of forest vegetation in recent years, the research of Laura Vārpiņa (Liepiņa) and Ralfs Čākurs can be mentioned. In her study, Liepiņa (2016) assessed the impact of orienteering competitions on the forest floor in two territories - the 47th stage of the orienteering club "Auseklis" competition series "Magnēts" in Inčupe-Bātciems (seaside) and the XXIX Orienteering three-day competition "KĀPA 2015" territories. The number of participants in the competition "KĀPA 2015" was almost 2000 , while in "Magnēts" it was smaller. The study confirms the hypothesis that the effect of trampling does not have a significant effect on the forest floor, except for the moss layer in one of the study objects (seaside). There it has also been observed that trampling has the greatest impact on vegetation on the hill tops and slopes of inland dunes and hills, and it has the least impact on micro-depressions and in Vacciniosa. Čākurs (2019) studied the impact of orienteering competition "Kāpa 2018” on vegetation. 1825 participants took part in this competition. Significant impact of trampling was observed only in a short period of time. Vegetation recovered very quickly - a month after the competition. The biggest impact of trampling was observed on the moss floor and on the slopes of dunes and hills. After both of these studies, it can be concluded that the impact of orienteering competitions in the territory of Latvia is observed in the most sensitive places, however, the vegetation is restoring relatively quickly.

The aim of the research: to assess the impact of orienteering competitions on ground vegetation in pine forests at the seaside, Latvia. In order to achieve the aim, the following research tasks have been set: to analyse the vegetation around the orienteering control points before and after the competition and to compare and evaluate the changes of vegetation in the terrain on the hill tops and in depressions. 


\section{MATERIALS AND METHODS}

In order to assess the impact of orienteering competitions on ground vegetation, two research objects have been selected from orienteering competition "World Masters Orienteering Championships 2019" or "WMOC 2019" competition area which was situated in the seaside near Bumbukalns and Garezeri (Figure 1). The competition took place from July 5, 2019 to July 12, 2019 and gathered more than 3000 participants, which was the largest competition in Latvia that year. The competition was organized by the Latvian Orienteering Federation in cooperation with the International Orienteering Federation.

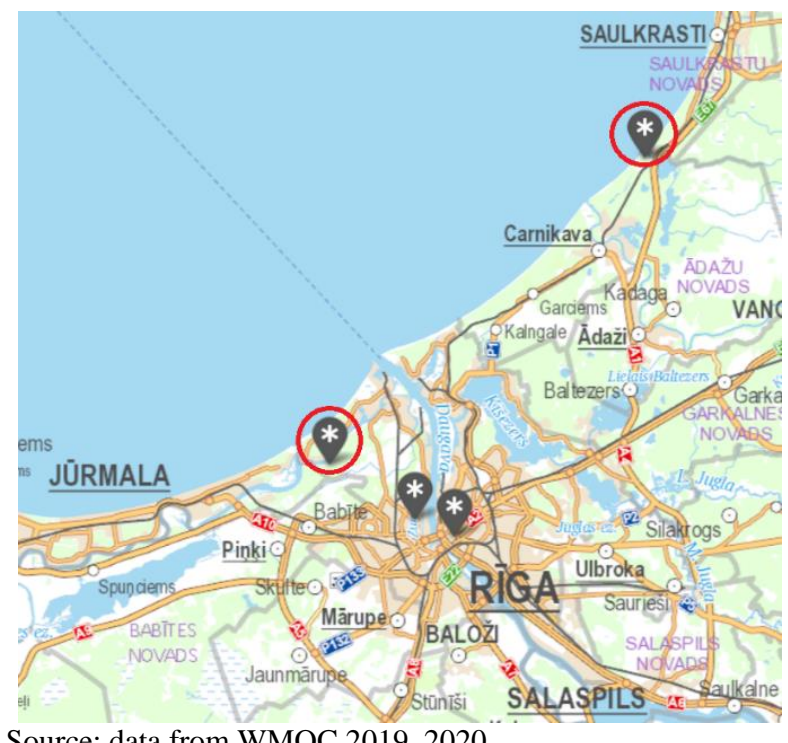

Source: data from WMOC 2019, 2020

Figure 1. WMOC 2019 competition areas

Bumbukalns is located in the northwest of Riga near Bullupe - the tributary of the old Lielupe in river Daugava. Bumbukalns belongs to the green zone of Riga (Sūna, 1973). Dunes covered with pine forests are typical for the competition area. It has a dune relief with various hill shapes. In some places the terrain is flat, but in other places dune ridges and hills reach a height of 20 meters. In several places, openings can be found as well as thick undergrowth. It is easy to run through the pine forests nevertheless area is technically complex (LOF, IOF, 2019). In the competition area two forest types were recognized - Cladinoso-callunosa and Vacciniosa, where a small number of species and poor soils are common. The territory of Bumbukalns is included in the SPNT "Bullu kāpas" and belongs to the nature reserve zone of this SPNT. In the competition area the European Union protected habitat 2180 Wooded seaside dunes can be found (Nature Conservation..., 2020).

Garezeri, where the competition in the long distance took place, is located northeast of Riga, on the Baltic Sea coast, near the village of Lilaste in Carnikava region (Figure 1). The competition area is characterized by sand dunes covered with pine forests. The area is filled with distinct hills and dune ridges of various sizes, but swampy places can also be found there. Garezeri is included in the Seaside Nature Park, most of it is the nature reserve area, but some areas are included in the nature park area as well (LOF, IOF, 2019). In this competition area two forest types were recognized - Cladinoso-callunosa and Vacciniosa, which are characterized by a small number of species and poor soils. In the competition area there is the European Union protected habitat 2180 Wooded seaside dunes (Nature Conservation..., 2020).

The collection of data required for the study took place in July 2019 before and after the competition. A total of 10 control point locations were selected at the sites, of which 4 were located in hill tops, 4 in depressions and 2 were finish checkpoints. 9 circular sample plots (each with a radius of $1.78 \mathrm{~m}$, area $10 \mathrm{~m}^{2}$ ) were established at the locations of control points (Figure 2). A total of 90 sample plots were established in the study.

Vegetation was counted in each sample plot using the Braun-Blanquet method (Pakalne, Znotinga, 1992). In each sample plot the total projected cover (\%) of vegetation and each species were determined in each floor: the tree layer E3 (trees higher than $7 \mathrm{~m}$ ), the shrub layer E2, which also includes growing trees (0.5-7 $\mathrm{m}$ tall trees and shrubs), the herbs layer E1 (including young trees and shrubs, which do not exceed $0.5 \mathrm{~m}$ in height) and the moss layer E0. The compliance of the forest habitat with an EU protected habitat has also been determined in the sample plots.

Digitization of the data obtained in the study was performed in the computer program MS Excel, where data on the composition of species from all of the sample plots were collected.

In each sample plot the total number of plant species according to their life form were determined, and in each forest stand floor species occurrence in each sample plot, average projective cover for each forest stand floor, Ellenberg indicator values in herbaceous plant layer and number of orienteering competition participants in each control point were determined.

The species occurrence coefficient is calculated according to the Raunkier formula (1), which describes how often the given species is present in all surveyed sample plots together: 
where

$$
R=100 * \frac{a}{n}
$$

$\mathrm{R}$ - the species occurrence coefficient;

$\mathrm{a}-$ the amount of sample plots, where the given species is present;

$\mathrm{n}-$ total amount of sample plots.

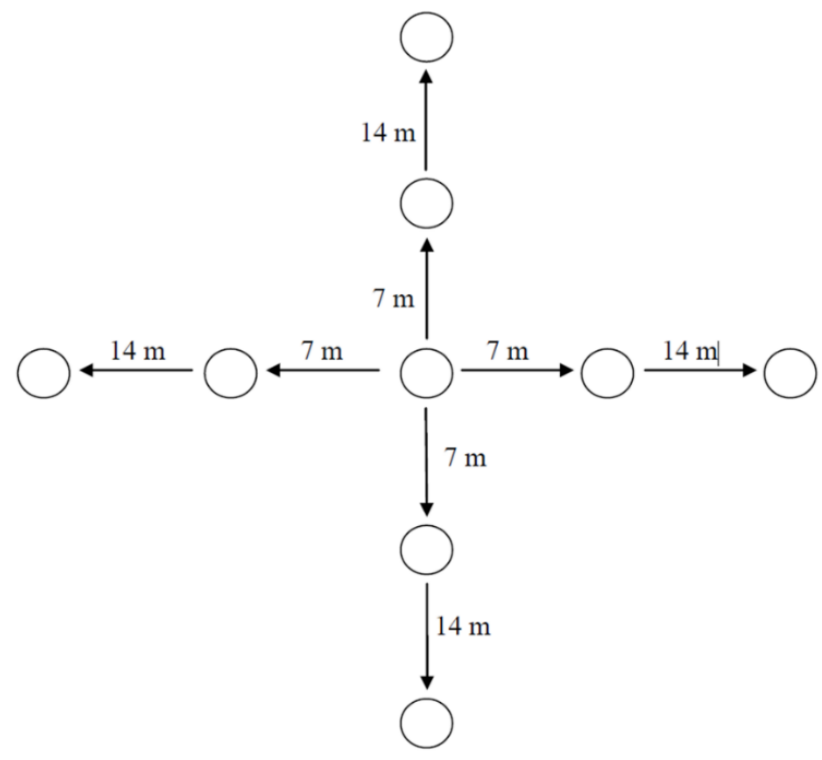

Figure 2. Sample plot layout plan (Liepina, 2016)

The occurrence of plant species in the sample plots is expressed by a constant index. It can be calculated by relating the number of plots where the species has been found to the total amount of plots: I - <21, II - $21-40$, III - 41 - 60, IV - $61-80, \mathrm{~V}-81-100 \%$ of the given species found in the plot (Muller - Dombois, Ellenberg, 1974).

The intensity of the trampling depends on the number of participants crossing the sample plots to check in the required control point. Using the data published about "WMOC 2019" concerning the results of the competition, the number of participants that have been at each control point has been calculated.

\section{RESULTS}

Characteristics and visual assessment of control points. In the territory of the orienteering competition "WMOC 2019" 10 sample plots were inspected. The centres of the sample plots were located at the control points. The type of terrain and forest type were determined in the sample plots, as well as other features about the control point. Out of 10 plots, 4 are located in hill tops, 4 are located in depressions and 2 plots are in flat terrain. Seven plots are located in the Cladinoso-callunosa, only three plots - in the Vacciniosa. All 10 plots are located in the habitat of wooded seaside dunes (European Union protected habitat 2180 Wooded seaside dunes).

Vegetation analysis. 29 species of vascular plants and mosses were identified in 10 sample plots. The number of species in each forest stand layer is shown in Table 1. In Cladinoso-callunosa it is typical - undergrowth is usually rare or non-existent. It is common in Cladinoso-callunosa and Vacciniosa that more than 50 species of vascular plants, lichens and moss grow (Liepa et al., 2014), therefore the study area is species-poor. Comparing the total number of species in the sample plots, it is clear that there are more species in the plots with a forest type of Vacciniosa. In general, the number of species is still very small in all plots, but this is typical for forest types such as Cladinoso-callunosa and Vacciniosa, as they have dry, nutrient-poor growing conditions.

Occurrence of species. In order to characterize the frequency of occurrence in all plots of the given species, the species occurrence coefficient was calculated, and the constancy class of the given species was determined. Four of the species were found in all plots: Pinus sylvestris, mosses - Pleurozium schreberi, Dicranum undulatum, Hylocomium splendens. These species are very common for both forest types (Cladinoso-callunosa and Vacciniosa) (Liepa et al., 2014). Four species are very common: Lerchenfeldia flexuosa, Melampyrum pratense, Cladina rangiferina and Cladina arbuscula (Indriksons, 2014). Occurrence of other species is rare. The proportion of species of constancy class V in the sample plots overall is high, indicating that the growing conditions in the plots are similar and stable, moreover suitable for these species.

No differences in the number of species were observed in the sample plots before and after competition, and accordingly the proportion of constancy classes is unchanged.

Projective coverage of species. By visually determining the average projective coverage of the forest layers in each sample plot before the competition, there is a pronounced predominance in the moss layer, because, as it is typical in Cladinoso-callunosa and Vacciniosa, many species of moss and lichens are present in the forest stand (Liepa et al., 2014). The moss layer occupies on average $68,8 \%$ of the area in each sample plot. The average projective cover of the 
herbs layer is $15.8 \%$, but the shrub layer practically is non-existent, whereas the tree layer covers only $2 \%$ of the plot area. It can be concluded that although Scots pine is found in all sample plots on the tree layer, its projective coverage is small. The moss layer dominates in all sample plots, where the largest coverage was formed by Pleurozium schreberi, Dicranum polysetum and Hylocomium splendens. In the herbs layer with the largest coverage was observed Vaccinium vitis-idaea, Lerchenfeldia flexuosa, Calluna vulgaris and in some places Vaccinium myrtillus also showed a very large coverage.

After the competition, changes in the projective coverage in the sample plots were detected only in the moss layer. On average, the projective coverage of the moss layer has changed by $3.03 \%$, that is, after the competition the average coverage was $66.9 \%$. Changes in the projective coverage of the moss layer were not observed in all sample plots. The largest difference in percentage of projective coverage was observed in sample plots - one located on a hill top and the other in a depression. For other sample plots, the changes in the projective cover of the moss layer before and after the competition varies from $1.88 \%$ to $5.36 \%$. Although visually it seems that after the orienteering competition the participants have trampled the ground vegetation, the impact is small and insignificant, so the ground vegetation will be able to recover in a short period of time.

\section{CONCLUSIONS}

Orienteering competitions do not significantly affect the forest floor.

No differences in the number of plant species were observed at the competition control points before and after the competition, respectively, the proportion of constancy classes is also constant.

The effect of trampling is observed only in the moss layer. In $10 \mathrm{~m}^{2}$ sample plots, the projective coverage of the moss layer has decreased on average by $3 \%$. No impact of trampling has been observed on other layers of the forest stand.

The biggest vegetation damage can be seen at the control point itself. The greater the distance from the control point, the lower the trampling intensity.

There is no correlation between the shape of the relief at the control point and the trampling intensity. Regardless of the location of the control point whether it is on the hill tops or in a depression, small differences in trampling intensity were found at control points with a similar number of visitors.

Acknowledgements. The study was supported by the grant of project of Latvia University of Life Sciences and Technologies "Implementation of LLU research programme".

\section{REFERENCES}

1. Ancient history. 2020. Available at https://sites.google.com/view/os-karte/senie-laiki/senā-vēsture?authuser=0

2. Čăkurs, R. 2019. Impact of orientering sport on vegetation. Bachelor's paper. Faculty of Geography and Earth Sciences, University of Latvia.

3. Encyclopaedia Britannica. 2020. Orienteering. Available at https://www.britannica.com/sports/orienteering

4. History and Facts About Orienteering. 2020. Available at https://www.athleticscholarships.net/other-sports-orienteering.htm

5. Indriksons, A. 2014. Forest typology. Forest botany and typology. Plants - indicators of growing conditions. Forest faculty, Latvia University of Life Sciences and Technologies. Student association „Šalkone”, pp. 85-89.

6. Laininen, E. 2012. IOF Survey - Orienteering and the Environment. Available at https://orienteering.sport/iof/environment-andsustainability/

7. Latvian Orienteering Federation. 2020. Results of orienteering competitions. Available at https://lof.lv/seriali_rez/stati

8. Liepa, I., Miezīte, O., Luguza, S. 2014. Forest typology. Specifics of Latvian forest typology. Forest faculty, Latvia University of Life Sciences and Technologies. Student association „Salkone”, pp. 5-65.

9. Liepiņa, L. 2016. Trampling effects of orienteering on forest ground cover in hilly areas. Master paper. Forest faculty, Latvia University of Life Sciences and Technologies.

10. LOF, IOF. 2019. WMOC_2019_Bulletin2. Available at https://www.wmoc2019.lv/augsuplades/files/WMOC_2019_Bulletin2.pdf

11. Muller - Dombois, D., Ellenberg, H. 1974 Aims and Methods of Vegetation Ecology. John Wiley \& Sons, Inc.

12. Nature Conservation Agency. 2020. OZOLS - Nature data management system. Available at https://ozols.gov.lv/pub

13. NCA and LOF working group recommendations. 2014a. Summary. Normative acts for organizing orienteering sports competitions in SPNT and particular habitats. Latvian Orienteering Competition. Available at https://lof.lv/uploads/Admin/DAP/ Kopsavilkums_NA.DOCX

14. NCA and LOF working group recommendations. 2014b. Process of organizing orienteering sports competitions, reducing the environmental impact. Latvian Orienteering Competition. Available at https://lof.lv/uploads/Admin/DAP/DAP_LOF_procedura_ gala_20_05_2014.xlsx

15. Pakalne, M., Znotiņa, V. 1992. Vegetation classification: Brown-Blanket method. University of Latvia.

16. Sūna, Ž. 1973. Green areas of Latvian SSR cities and towns. Liesma.

17. Чижова, В. П. М. 1977. Рекреационные нагрузки в зонах отдыха. Лесная промышленность. 